\title{
Re-Contextualizing Introductions
}

Dostoevsky wrote and published The Diary of a Writer (Dnevnik pisatelia) in 1873, then terminated the series to write a second novel-experiment, The Adolescent (Podrostok, 1875). ${ }^{1}$ Upon that novel's completion, he took up The Diary again for the years 1876 and 1877, put it aside yet again to write The Brothers Karamazov, and returned to The Diary for only occasional publications in 1880 and $1881 .^{2}$ There are very few fictional offspring birthed in The Diary, but cousins crop up regularly. Morson labels these kin semi-fictions. They include reportage that drifts in and out of imaginings that, in some measure, constitute fictionalized narratives. Consequently, an immediate complication in studying introductions in The Diary of a Writer is that it is difficult to tell what is an introduction and what is not. This may seem to overstate the case when dealing exclusively with the prefaces to Dostoevsky's prose fiction. But in the context of the The Diary, a prefatorial aura surrounds each of the overt prefaces that accompany the stories Dostoevsky created for The Diary as well as the fiction that lacks a preface proper. Robert Louis Jackson summarizes the interaction of texts, pre-texts, and post-texts,

1 The first novel-experiment being Demons (Holland, The Novel in the Age of Disintegration, 101-130).

2 These final two years of The Diary contain no fiction. The Diary presents, among its extensive journalistic entries, feuilletons, physiological sketches, and other narrative forms that represent something between fiction proper and overt imaginative excursions of a quasi-fictional nature (Gary Saul Morson, "Introductory Study: Dostoevsky's Great Experiment," in Fyodor Dostoevsky, A Writer's Diary I, trans. and ed. Kenneth Lantz [Evanston: Northwestern University Press, 1994], 1-117). 
referencing one example that can be applied fairly to each of the three instances we treat here:

["The Boy at Christ's Christmas Party"] appears in Dostoevsky's Diary of a Writer, January 1876, chapter two. It is bracketed by two other sketches devoted to the plight of poor, homeless street boys. The first extremely brief sketch, "A Boy with his Hand Outstretched for Alms" ["Mal'chik s ruchkoi"], forms a kind of prologue to "A Boy at Christ's Christmas Party" ["Mal'chik u Khrista na elke"]. The third sketch in the trio, "A Settlement for Juvenile Delinquents" ["Koloniia maloletnikh prestupnikov"], is given over to a description of a reform institution and the problem of the "conversion of wanton souls into virtuous ones." 3

There are three ways in which Dostoevsky's Diary prefaces interact with the fiction that appears therein. First, as Morson argues, the prefaces are absorbed into the text they introduce, forming a part of those texts rather than standing outside their discursive umbrella. Second, any preface may be correlated or integrated with other prefaces appearing within the The Diary. They may be assessed in relation to the discourse of both non-fictional and semi-fictional introductions. And third, the Dostoevsky prefaces that immediately precede The Diary's fiction can be viewed within the overall pattern of the entire set of texts that make up all of The Diary of a Writer.

Dostoevsky uses prefaces frequently in The Diary. They are not fictional. There are occasions when a non-fictional entry becomes, or emerges in the process of Dostoevsky's writing, as an introduction to one of his occasional fictional pieces. In many respects, the context of meta-utopian discourse swallows them into a hole of generic ambiguity. It would be inadmissible, Morson argues, to separate Dostoevsky's fictional pieces in The Diary from the overarching conception of its entirety, an entirety or integrated whole, it must be added, that emerges and evolves with each issue. Just as much as "meta-utopia runs the risks of its genre: namely, that its heterogeneity will be perceived as chaos, that its multiple points of view will be seen as incoherence or reduced to singularity, and that the network of allusions and repetitions which link its parts will be taken as no more than recurrent concerns," so the fictional works housed in The Diary and their prefaces

3 Jackson, The Art of Dostoevsky, 260-261. 
might best be viewed for their part across the entire series. ${ }^{4}$ When we examine Dostoevsky's introductions to the short stories that appear in The Diary, we can view them either as discrete objects of the type we have encountered up to this point in his fiction, or as part of a unified design (e.g., meta-utopian discourse). The stories, then, stand alone as individual works whose context(s) are created out of the writing enterprise itself, and simultaneously as integral parts of the meta-utopian genre in which the stories' own generic impulses represent individual instantiations of the whole. ${ }^{5}$

This complex interaction across generic boundaries forces us to acknowledge something we have not had to previously. Were we to continue to isolate Dostoevsky's prefaces to the fiction as we have to this point-permitting them to speak from out of the context fictional discourse relies upon and reifies at each of its instances-we might distort their place within the aesthetics of their containing discourse and within their overriding boundary-genre structure. We proceed, therefore, with caution.

\section{I \\ "BOBOK"}

If the force of Morson's argument is strong enough to be taken to heart in the treatment of the whole of The Diary and its fictions, it may not be necessarily binding for Dostoevsky's fiction in The Diary's inaugural year, that is, long before the overarching design of the entire project became more clear to him or, alternatively, before the impulses

4 Morson, Boundaries of Genre, 175.

5 Morson writes: "Like its generic relatives, the Diary invites interpretation as a 'dialogue of the mind with itself,' an 'adventure of the soul among Utopian inquiries." And further, "The antitheses of metaliterary play and dogmatic assertion [in the Diary] produce meta-utopian ambivalence-that is, not a synthesis, but an intensified dialectic of utopian 'pro' and anti-utopian 'contra.' That dialectic is, in turn, the reflection of Dostoevsky's deepest ambivalence toward what he regarded as the most fundamental moral, religious, and political issues" (Boundaries of Genre, 177). 
of his spontaneous writings developed into that design over time. ${ }^{6}$ In the 1873 series of The Diary, only one fictional piece appears for the entire year. Most entries consist of Dostoevsky's rebuttals to criticism, anecdotes, feuilletons, physiological sketches, and explicitly noted semi-fictions. It is worth mentioning that in this last instance Dostoevsky clearly engages the techniques of fictional discourse, but he does so overtly, informing the reader at each step that he is extrapolating upon what strikes his eye as he walks the streets of St. Petersburg, spinning tales he subsequently writes down, but without attempting to create an illusion of some discursive reality that invites readers to suspend disbelief. This practice includes "Bobok," that sole piece of fiction for $1873 .^{7}$

Dostoevsky prefaces this crazy fiction-a dialogue of the dead overheard by someone in a cemetery who is most likely sleeping off a drunk-with the briefest foreword we meet in Dostoevsky's corpus: “On this occasion I shall include 'The Notes of a Certain Person.' That person is not I, but someone else entirely. I think no further foreword is needed." 8

Our focus is first on the function of the preface. As we have seen repeatedly, Dostoevsky's forewords usually fulfill some combination of three functions. They identify the genre of the work, introduce the central character or characters, and deliver up an explanatory note (explicitly or covertly) on the often unreliable narrator's manner of speech as it represents his point of view. These functions, shared across all the prefaces we have examined, are matched by an important set of differences. As we have seen, Dostoevsky continually shifts the source of information from one work to another. In The Village of Stepanchikovo, we have a fictional authorial (and somewhat actorial) narrator who introduces his narrative. In Notes from the House of the Dead, we hear first from a fictional editor who has purloined the text he presents. In Notes from the Underground, Dostoevsky's signature suggests an authentic authorial introduction, but the Underground

6 It is widely understood that Dostoevsky did not retain his original intent and that The Diary altered after 1873.

7 "Bobok" is most often left without translation. It has an absurd ring to it. In Russian it sounds like "little bean," but its referent is detached from the signifier.

8 Dostoevskii, PSS, XXI: 41; Fyodor Dostoevsky, "Bobok," in A Writer's Diary, trans. Kenneth Lantz (Evanston: Northwestern University Press, 1994), I: 170. 
Man's speech intrudes and we surmise that we have before us two voices in dialogue with each other, which creates a hybrid form of fictional actorial and authorial utterance.

It is difficult to fix the parameters of fictionality, authoritativeness, and reliability in Dostoevsky's introductions, for they are alternately paradoxical, self-nullifying, or simply illogical. Each ultimately forces readers to shift focus from the ostensible object of depiction to the subject whose voice delivers up character and event, scene and dialogue. ${ }^{9}$ Consequently, discourse is raised to the level of covert theme, thereby encouraging readers to engage the ensuing narrative as a charged form of expressive language. This approach to introductions, however, is destabilized in the prefaces to the fiction of The Diary where Dostoevsky appears to speak directly on his own behalf and in his own voice to the reader, as he seemed to do in Winter Notes on Summer Impressions.

"Bobok" follows Dostoevsky's initial four entries for 1873. Each of them is dedicated to a single topic: Belinsky; jury trials; Chernyshevsky; and Nekrasov's poem "Vlas." After these essays and feuilletons, the reader encounters the allegory, "Bobok," with its remarkable caution: "[The narrator] is not I, but someone else entirely." That "not I" commences to recount his grave experience, the fantastic nature of which is explained away in the narrator's first line of the tale: "The other day Semyon Ardalonovich up and said to me, 'Ivan Ivanych, tell me, for Heaven's sake, will there ever be a day when you'll be sober?" ${ }^{10}$ Rather than seeing pink elephants, Ivan Ivanych hears the dead speak. "Bobok" is a travesty on human foibles and pettiness-we apparently carry them to the grave with us for safe keeping.

Dostoevsky hardly need forewarn us that he is not the besotted Ivan Ivanovich. But because the previous (and initial) entries to The Diary have all come from the implied author's voice, Dostoevsky may have felt it necessary to indicate that he was altering the pattern

9 In his treatment of “A Gentle Creature," for example, Michael Holquist examines the distinction between subject and object, in particular "the structural resistance the tale offers to its own apparent theme, the way the fact of the narrator's monologue, his own voice, undercuts his stated desire for harmony, more than one voice" (Dostoevsky and the Novel [Princeton: Princeton University Press, 1971], 148).

10 Dostoevsky, A Writer's Diary, 170; 41. 
and providing readers with a fiction recounted from the position of another person. But what reader couldn't surmise that without the caution? Only the most naïe, who would then have to presume that Dostoevsky qua narrator is the drunk Semyon Ardalonovich. Joke aside, Dostoevsky establishes a hierarchy of readers here. He draws those who perceive the joke into a network of the like-minded; and he ridicules other, less adept readers who, quoting Lermontov again, "fail to understand irony."

Throughout The Diary Dostoevsky plays with the notion of readership, projecting different capacities on different types of reader. What is significant in the introduction to "Bobok," however, is that Dostoevsky lays bare the device that he has used to this point in his fiction-all the prefaced texts we have examined are narrated by someone "not Dostoevsky." The introduction to "Bobok" provides belatedly an invariant governing Dostoevsky's prefaces from the beginning.

\section{II \\ "THE BOY AT CHRIST'S CHRISTMAS PARTY"}

The second piece of fiction Dostoevsky delivers up appears three years later in the January issue of the renewed Diary for 1876. "The Boy at Christ's Christmas Party" contains two authorial introductions, one preceding the text and the second embedded covertly within it. They reveal Dostoevsky in the process of inventing a story, moving from what he has observed in the streets of St. Petersburg to mental wanderings about the plight of people he has encountered en masse to then imagining them all reduced to a single, representative figure, the little boy of the story's title. In the first introduction, the entry titled "A Boy with His Hand Outstretched for Alms," we encounter a feuilleton cum physiological sketch: "Children are a strange lot; I dream of them and see them in my [imagination]. In the days before Christmas and on Christmas Eve itself I kept meeting on a certain street corner a little urchin who could have been no more than seven." 11 Dostoevsky

11 Dostoevsky, A Writer's Diary, I: 309; Dostoevskii, PSS, XXII: 13. 
goes on to describe the child, the Dickensian background of the child's begging (to support "a band of dodgers' drinking habits"), the boy's techniques for securing a few kopecks from passers-by, and the likelihood of a life of crime and misery. Dostoevsky concludes his remarks with a clear idea in his mind as to where his sketch is leading him: "A wild creature such as this sometimes knows nothing at all-neither where he lives, nor what nation he comes from; whether God exists, or the tsar. There are even stories about them that are hard to believe, yet they are facts." 12

Dostoevsky tells one such story and transitions to it in two steps, shucking his authorial persona in the process. First he maintains his authorial stance: "But I am a novelist and one 'story,' it seems, I made up myself. Why do I say 'it seems' when I know very well that I made it up? Yet I keep imagining that it really happened somewhere, sometime, and happened precisely on Christmas Eve in a certain huge city during a terrible cold spell." 13 Then he shifts from direct authorial voice to the voice position intermediate between authorial persona and omniscient narrator: "I dreamed there was a boy-still very small, about six or even younger-who awoke one morning in the damp and cold cellar where he lived. He was wearing a wretched wrapper of some sort and he was trembling ... he was very hungry." ${ }^{14}$ In a third move, the omniscient narrator takes over and the tale commences: "Several times that morning he had approached the bed on which his sick mother lay on a mattress as thin as a pancake, a bundle beneath her head to serve as a pillow. How did she come to be here?" 15 The narrator flushes out his characters, their abject condition, and the boy's heart-wrenching death behind a woodpile where he has crawled after having viewed through a window the grandeur and sumptuousness of St. Petersburg high society at celebratory play.

Dostoevsky's brief introduction to "The Boy at Christ's Christmas Party" represents the first half of a frame that the omniscient narrator closes at the story's end. He shifts back to a position somewhere between his authorial persona and his narrator's voice. In this guise he delivers a sermon about the place Christ has set for the boy at His

12 Dostoevsky, A Writer's Diary, 310; 14.

13 Dostoevsky, A Writer's Diary, 310; 14.

14 Dostoevsky, A Writer's Diary, 310; 14.

15 Dostoevsky, A Writer's Diary, 310; 14. 
celestial Christmas celebration. In "God's Heaven," the boy meets his mother, who "had died even before him." 16 Dostoevsky's authorial persona then returns fully to complete the narrative's symmetry:

So why did I make up a story like that, so little in keeping with the usual spirit of a sober-minded diary, and a writer's diary at that? All the more since I promised stories preeminently about actual events! But that's just the point: I keep imagining that all this could really have happened-I mean the things that happened in the cellar, and behind the woodpile; as for Christ's Christmas party—well, I really don't know what to say: could that have happened? That's just why I'm a novelist—-to invent things. ${ }^{17}$

The narrative framing that structures "The Boy at Christ's Christmas Party" represents an order of discourse quite distinct from the frame narratives of the second half of the nineteenth century in general and from the instances we have discussed previously in regard to Dostoevsky's earlier work. It was normative to develop a frame tale where the opening bit (the frame) is fictional, like the embedded or inserted tale contained within it. We think of Turgenev's "First Love" (1860) as exemplar, or, later in time, Chekhov's trilogy "The Man in a Case," "Gooseberries," and "About Love" (1898). But Dostoevsky's opener is not fictional. Consequently, it deprives the fictional discourse of the riches that accrue from framed narratives. There is no third story to be manufactured out of the interaction between the frame and insert tale. Indeed, Dostoevsky's tendentiousness is so overt in "The Boy at Christ's Christmas Party" that "The Boy" may provide indirect insight into why it is that Dostoevsky is most often inclined to speak in another's voice when building a narrative. When speaking on his own behalf Dostoevsky finds himself prone to provide the moral of his narrative in no uncertain terms. He removes alternate interpretations from the field of play and utters the text's final word. Such is not the case when Dostoevsky uses fictional introductions.

16 Dostoevsky, A Writer's Diary, 314; 17.

17 Dostoevsky, A Writer's Diary, 314; 17. 


\section{III}

\section{"THE PEASANT MAREI"}

The following month, in the February issue's first entry for 1876, Dostoevsky improved upon "The Boy." Not that he gave up on sounding a sentimental note. In "The Peasant Marei," both the appeal to the reader's heart and the use of a an authentic authorial voice are reminiscent of "The Boy." Dostoevsky, however, made the narrative context more complex and, thus, satisfying. "Marei" is preceded by one of Dostoevsky's editorials, titled "On Love of the People. An Essential Contract with the People" ("O liubvi k narodu. Neobkhodimyi kontrakt $\mathrm{s}$ narodom"). ${ }^{18}$ It sets the theme of the brief story, providing in the character Marei an exemplar of what Dostoevsky had addressed in abstract terms in his pre-foreword, "On Love of the People."

Dostoevsky doubles the complexity of relations between the tale's frame and the tale itself. After the preparatory "On Love of the People," "The Peasant Marei" presents a brief introduction in the author's voice, followed by a frame narrative that is autobiographical in nature and within which the insert story about the author and Marei occurs. It's a room full of mirrors from which a more deepened sense of what Dostoevsky is up to in The Diary can be gleaned.

Having been primed about one of Dostoevsky's criticisms of his homeland (the separation of the upper classes and intelligentsia from the common Russian), readers are provided evidence for the benefit to be derived from renewing ties with the folk. Proof comes by way of the peasant Marei. Dostoevsky begins in amusing fashion (critiquing his own piece on "The People"), then turns to furnishing his proof by way of narrative:

But reading all these professions de foi is a bore, I think, and so I'll tell you a story [anekdot]; actually, it's not even a story, but only a reminiscence

18 In keeping with an emerging structure that more and more often presents frames within frames, "On Love of the People" itself is introduced by yet another article: "On the Fact That We Are All Good People. How Russian Society Resembles Marshall MacMahon" ("O tom, chto my khoroshie liudi. Skhodstvo russkogo obshchestva s marshalom Mak-Magonom”). See Dostoevsky, A Writer's Diary, 343-355; 39-49. 
[vospominanie] of something that happened long ago and that, for some reason, I would very much like to recount here and now, as a conclusion to our treaties on the People. At the time I was only nine years old.... But no, I'd best begin with the time I was twenty nine. ${ }^{19}$

This is a fairly matter-of-fact utterance through which Dostoevsky's diary persona turns readers' attention to something more palatable than his rant about what's wrong with the country and how to mend its ways. He shifts toward storytelling. Not once, but twice. First he recounts an autobiographical sketch from his time in prison. His memory goes back to 1850 when he first entered the prison stockade. The frame narrative shifts next to the insert story that moves the temporal setting back yet again, this time to 1830 . The motion, like so much of Dostoevsky's fiction, shifts backward in time in order to recreate the current historical moment. ${ }^{20}$ "It was the second day of Easter Week.... I was wandering behind the prison barracks, examining and counting off the pales in the sturdy prison stockade, but I had lost even the desire to count, although such was my habit." ${ }^{21}$ The prisoner Dostoevsky is confronted by all manner of depravity during the festivities: "Disgraceful, hideous songs; card games; . . . convicts already beaten half to death by sentence of their comrades ...; knives had already been drawn ... all this, in two days of holiday, had worn me out to the point of illness." 22

Here Dostoevsky sets up a fundamental contrast, addressed already in his preparatory article on "The People," that serves his larger argument. This depravity represents the "husk" of the Russian peasant. Beneath it lies the glorious fruit. As he puts it in "On Love for the People," "One must know how to segregate the beauty in the Russian peasant from the layers of barbarity that have accumulated over it." 23 Dostoevsky fleshes out some of the barbarity as he, in a continual state of shock, encountered it upon entering prison. He suppresses the awful

19 Dostoevsky, A Writer's Diary, 351; 42 (Dostoevsky's ellipsis).

20 We think of Raskolnikov's dreams, for example, or the first two chapters of Part One of Demons, not to mention the setting of The Brothers Karamazov (fifteen years prior to the moment of narration).

21 Dostoevsky, A Writer's Diary, 351; 42.

22 Dostoevsky, A Writer's Diary, 351; 42.

23 Dostoevsky, A Writer's Diary, 347; 43. 
image of humankind by climbing onto his bunk and closing off his senses to the madness surrounding him:

I liked to lie like that: a sleeping man was left alone, while at the same time one could daydream and think. ... Little by little I lost myself in reverie and imperceptibly sank into memories of the past. All through my four years in prison I continually thought of all my past days, and I think I relived the whole of my former life in my memories. These memories arose in my mind of themselves; rarely did I summon them up consciously. ${ }^{24}$

At this moment in the frame narrative, Dostoevsky recalls one specific memory and how it acted upon his heightened sensitivities at the time. The front frame (the prison scene) closes and the memory of the peasant Marei begins.

It is an idyllic time and setting-the countryside in late summer with nature's beauty surrounding the nine-year-old Fyodor as he explores the family property looking for bugs, beetles, lizards, mushrooms, berries, birds, hedgehogs, and squirrels. The idyll is broken when he hears someone shout "Wolf!" Frightened to death, he runs to a peasant mowing the field adjacent to the thicket where he had been playing. We encounter with the narrator the beauty below the husk of the peasant: "What do you mean, lad? There's no wolf; you're just hearing [things,' he said], reassuring me. But I was all a-tremble and clung to his coat even more tightly; I suppose I was very pale as well. He looked at me with an uneasy smile, evidently concerned and alarmed for me."25

The central pieces of Dostoevsky's evidence then come forth. Marei touches the child thrice, each time indicating either a maternal gesture or a priestly blessing:

First, "he stretched out his hand and suddenly stroked my cheek." After delivering more reassuring words of comfort, Marei "quietly stretched out a thick, earth-soiled finger with a black nail and gently touched it to my trembling lips." The boy calms down and Marei says, "Well, Christ be with you, off you go," and makes "the sign of the cross over me, and crossed himself. I set off." 26 The child returns home with a look and wave back to Marei. The insert story then ends.

24 Dostoevsky, A Writer's Diary, 347; 43.

25 Dostoevsky, A Writer's Diary, 354; 48.

26 Dostoevsky, A Writer's Diary, 354; 48. 
The frame is taken back up and we return to Dostoevsky's depiction of his twenty-nine-year-old self in prison on his bunk surrounded by a topsy-turvy world of depravity. But the rank behavior of the inmates cannot touch him any longer: "I recalled the tender, maternal smile of a poor serf, the way he crossed me and shook his head: 'Well you did take a fright now didn't you, lad!' And I especially remember his thick finger, soiled with dirt, that he touched quietly and with shy tenderness to my trembling lips." 27 Marei is the wheat and the chaff, the skin and the fruit: "Of course, anyone would try to reassure a child, but here in this solitary encounter something quite different had happened, and had I been his very own son he could not have looked at me with a glance that radiated more pure love, and who had prompted him to do that?" 28 Here is Dostoevsky's evidence: the rough, dirtied hand; the touch of love and succor; the blessing. "Our encounter was solitary, in an open field, and only God, perhaps, looking down saw what deep and enlightened human feeling and what delicate, almost feminine tenderness could fill the heart of a coarse, bestially ignorant Russian serf who at the time did not expect or even dream of his freedom." 29

With his memory of Marei fresh in mind, Dostoevsky can now view "these unfortunate [prisoners] in an entirely different way and ... suddenly, through some sort of miracle, the former hatred and anger in my heart vanished." ${ }^{30}$ Dostoevsky's epiphany is complete and the frame tale ends. Readers, of course, are meant to duplicate Dostoevsky's insight and rest assured that the common people are indeed beautiful and capable of everything he has advanced in his argument in the preceding two journal entries.

As with "The Boy at Christ's Christmas Party," we are narrated into an emotional, perhaps even ideological corner. ${ }^{31}$ The Dostoevsky

27 Dostoevsky, A Writer's Diary, 355; 49.

28 Dostoevsky, A Writer's Diary, 355; 49.

29 Dostoevsky, A Writer's Diary, 355; 49.

30 Dostoevsky, A Writer's Diary, 355; 49.

31 The ideology being "nativeness" or "national/ethnic identity" (pochvennichestvo), which is indicated symbolically in Marei's blackened fingernails and soiled hands. See Wayne Dowler, Dostoevsky, Grigor'ev, and Native-Soil Conservatism (Toronto: University of Toronto Press, 1982); Robert Louis Jackson, Dostoevsky's Quest for Form: A Study of His Philosophy of Art (New Haven: Yale University Press, 1966), 71-91; Dialogues with Dostoevsky: The Overwhelming Questions (Stanford: Stanford University Press, 1993), 237-241; 
who appears to speak in his own voice again attempts to reduce reader response to one option. Whether or not we readers submit to the response Dostoevsky seeks from us is beside the point. What matters here is that the authentic authorial preface in Dostoevsky's hands uniformly inclines in a monologic direction. The frame and insert narratives do not interact except as a motivational device linking the state of separation from the common people with a reunion with them. Other than that, the frame and insert tales do not mingle in such a way as to create a third tale, a covert story behind the crust of surface narrative. As touching as "The Peasant Marei" might be, it does not open out into dialogic possibilities. The impulse, as in "The Boy," is all in one direction-toward the implied author's position.

Sensing something out of place, or knowing that it is, Dostoevsky does not return to the practice of monologism again. But in the penultimate piece of prose fiction in the The Diary, "A Gentle Creature" ("Krotkaia"), he nevertheless engages direct authorial address again in his foreword. This time, rather than providing us with a sentimental tale of injustice, or a moving memory of contact with a good heart, and then telling us how to interpret it, in "A Gentle Creature" Dostoevsky returns to the techniques of his previous fictional introductions. In the story, Dostoevsky produces a multi-functional and densely encoded preface that he labels "From the Author" ("Ot avtora"). In it, Dostoevsky's discourse reflects the notion that language can create meaning in the process of actively seeking it. For this, something more complex than a graveyard allegory, an outworn sentimental tale, or a memory of a kind peasant is required.

\section{IV}

\section{“A GENTLE CREATURE”}

By utilizing the distinctive sign "From the Author," Dostoevsky forces a separation of previous diary entries from this one, if only in a formal sense. For we know that The Diary's entries always come "from the

and Close Encounters: Essays on Russian Literature (Boston: Academic Studies Press, 2013), 211-225. 
author." What the foreword's title indicates is that a change is afoot-he is about to tell a story. Not just any story, but one that differs from his previous attempts. The author's intent appears to have altered, and his design for the narrative with it, for he begins the November issue of The Diary with this story, not with an article preceding it that might be configured into a frame structure that in some manner anticipates the narrative and in some manner shapes it.

After begging his reader's indulgence for including a piece of fiction in his diary entry (a rather shopworn opening), Dostoevsky immediately turns to two literary matters that concern him greatly-the often fantastic nature of reality and associated problems of depicting it plausibly in fiction: "Now a few words about the story itself. I called it 'fantastic,' even though I consider it to be realistic in the highest degree [v vysshei stepeni real'nym]." ${ }^{32}$ Dostoevsky does not wish to clarify his self-contradictory statement too quickly, seeking instead to draw readers into the text at this early moment by creating and sustaining a level of cognitive dissonance.

It must be observed that Dostoevsky's use of this seeming paradox at the outset not only hooks his readers intellectually in the discourse, it duplicates the very type of speech readers soon encounter in the pawnbroker-narrator's monologue. As Dostoevsky himself puts it later in the introduction when characterizing his fictional narrator: "Despite the apparent coherence of his speech, [the pawnbrokernarrator] contradicts himself several times, both logically and emotionally." ${ }^{3}$ This can be said, too, of the implied author of the preface. There are affinities, in other words, between the narrator's utterances in the story and Dostoevsky's discourse in the introduction. This affinity is not only a matter of logic, or the lack of it, but of feelings as well. To sort out the contradiction that the author finds superficial, Dostoevsky attempts twice, in the third and fourth paragraphs of the introduction, to explain himself: "But [the story] truly does contain something fantastic, which is the form of the story itself, and it is this which I find necessary to explain beforehand." 34

Having promised now to give his readers an explanation of an apparent paradox, Dostoevsky does not present us with a syllogism,

32 Dostoevsky, $A$ Writer's Diary, I: 677; Dostoevskii, PSS, XXIV: 5.

33 Dostoevsky, A Writer's Diary, 677; 5.

34 Dostoevsky, A Writer's Diary, 677; 5. 
let us say, or a series of rational arguments to support his assertion. ${ }^{35}$ Rather, he sets before the reader a scene, a character, and a problem of interpretation. In other words, in the third paragraph of the introduction Dostoevsky turns from the problem of genre (the fantastic vs. the realistic) to the question of narrative technique, outlining his story and then presenting readers with information both about his narrator and his peculiarities of speech. Delaying any discussion of the generic problem until the final (fourth) paragraph of the introduction, Dostoevsky at this moment focuses reader attention on the problem of language and utterance. In this way the third paragraph becomes central to any appreciation of Dostoevsky's language as an object. That language, below the surface level of normative speech, is pregnant with covert meaning. Dostoevsky and his narrator utilize language as a medium of inquiry and as a repository of potential meaning. Readers are meant to absorb both simultaneously. In "A Gentle Creature" we are dealing with a process through which the implied author and the narrator are thematized as seekers of a truth contained in the expressive, de-automatized capacities of language. ${ }^{36}$

Readers are asked to join the author and narrator in terms of their understanding of plot and character. One level shared by them is temporal in nature and has to do with a primary opposition at work in text: before/after. In thematic and plot terms, the pawnbroker discovers after his wife's suicide that he had ample forewarning of the impending tragedy. At the auctorial level, Dostoevsky prepares his reader both generically, thematically, and in terms of discourse, for what follows the introduction. Depending upon readers' sensitivity to the text, their experience either duplicates the one toward which Dostoevsky gestures in his introduction or toward that of the pawnbroker. If readers take Dostoevsky's cues, they find themselves amply prepared in advance for the narrator's monologue with all its psychological and dialogical complexity. If they do not, after the conclusion

35 V. A. Sidorov long ago argued that we should not expect to find forms of logical argument in The Diary. He sees, and correctly so, that The Diary is a work of art above all else ("O Dnevnike pisatelia," in Dostoevskii: Stat'i i materialy: sbornik statei 2, ed. A. S. Dolinin [Leningrad-Moscow: Mysl', 1924], 109-116).

36 Isenberg raises the question of whether language can perform this service either for the narrator or for Dostoevsky. He argues that the role of silence in the story is hermeneutically significant (Telling Silence, 68-76). I advance the argument that de-automatized utterance speaks volumes. 
of the story they are called upon to duplicate the narrator's quest for understanding and to ferret out the myriad details of plot and character psychology that confound the narrator himself, and to seek belatedly the truth the narrator attempts to discover.

The temporal opposition between before and after is insinuated into the text in Dostoevsky's introduction: “[The story] truly does contain something fantastic, which is the form of the story itself, and it is this which I find necessary to explain beforehand." This innocuous temporal adverb is anything but, for, in the narrator's mind, everything hinges on his understanding of the causes of his wife's suicide. Had the narrator of the tale been able to decode the cues of his wife's approaching leap, icon in hand, from a window, as he tells us in self delusion later, the tragedy could have been averted. ${ }^{37}$ In like manner, if readers decode the temporal and spatial clues embedded in the introduction (which the narrator, of course, is not privy to), they become better equipped than the narrator to comprehend the tragedy.

The narrator ruminates beside his deceased wife who "only a few hours earlier has killed herself by jumping out a window." 38 He attempts to understand why his wife, the Gentle Creature, has died by suicide. By introducing the issue of causality in the introduction, Dostoevsky involves readers in the interpretation of the problem even before the monologue begins. In effect, the narrator and his readers attempt to interpret what has happened together, even simultaneously. Consequently, subject/object relations become blurred and deep affinities are created between author, narrator, and reader.

Repetition plays an important role in the introduction, the most blatant form represented by the expression "to gather [one's] thoughts into a point" (sobrat' mysli $v$ toch $k u$ ). It occurs on three occasions within the third paragraph of the introduction, each time in a different form. First it occurs in the implied Dostoevsky's own voice under the imprint of the genitive of negation: "He is in a state of bewilderment and still has not managed to collect his thoughts" (Onv smiatenii $i$ eshche ne uspel sobrat' svoikh myslei). ${ }^{39}$ In the next two remarks, Dostoevsky presents the idea within quotation marks. This signals a movement away from Dostoevsky's speech position toward that of the

37 Dostoevsky, A Writer's Diary, 714; 33-34.

38 Dostoevsky, A Writer's Diary, 677; 5.

39 Dostoevsky, A Writer's Diary, 677; 5. 
pawnbroker-narrator. First Dostoevsky defines just what he means by the phrase: "He paces through his apartment, trying to make sense out of what has happened, to "focus his thoughts." 40 By setting the expression off as quoted speech, Dostoevsky in effect cites the pawnbroker who, in the first chapter, utilizes the phrase himself an additional three times. ${ }^{41}$ By repeating the pawnbroker's own expression, Dostoevsky reverses the reader's temporal encounter with the text, signaling again the opposition before/after. In calling forth the pawnbroker's speech before it occurs in the text, Dostoevsky engages in a temporally complex form of double-voiced speech. ${ }^{42}$ Writer and narrator are again linked to each other.

In the third use of the phrase, Dostoevsky foretells what occurs in the narrator's quest for the truth: "Little by little he really does make the matter clear to himself and gather 'his thoughts into a point." 43 The phrase is repeated here in yet a third variant. This time the verb is not enclosed in quotation marks but the rest is. This consigns the verb "to gather" (sobrat') to Dostoevsky's voice and its direct object to the narrator's. In sum, the verb occurs three times in the introduction, twice within the technical confines of Dostoevsky's own speech. From this perspective it is possible to join the verb of "gathering" or "collecting" not only with the narrator's personal search for the truth, but with Dostoevsky's search for a means by which to encapsulate the narrator's search. Both quests implicate readers, drawing them into a similar effort to comprehend the coincident truths of the narrative. Three processes of interpretation are themselves gathered into a point-the pawnbroker's struggle to comprehend what has happened, Dostoevsky's struggle to encode the pawnbroker's quest, and readers' attempts to render the two comprehensible, if not meaningful.

40 Dostoevsky, A Writer's Diary, 677; 5.

41 Dostoevsky, A Writer's Diary, 678-683; 6-10.

42 Bakhtin would call this the "active" form of double-voiced speech, which he defines as "discourse with an orientation toward someone else's discourse." The active variety denotes "hidden internal polemic," "any discourse with a sideward glance at someone else's word [ogliadka na chuzhoe slovo]," a "rejoinder," "hidden dialogue" (Problems of Dostoevsky's Poetics, trans. Caryl Emerson [Minneapolis: University of Minnesota Press, 1984], 197-199; M. M. Bakhtin, Sobranie sochinenii v semi tomakh, 2 [Moscow: Russkie slovari, 2000], 220-223).

43 Dostoevsky, A Writer's Diary, 677; 5 (author's emphases; translation modified). 
In the overlapping forms that link encoding and decoding, matters of interpretation and interpenetration play central roles in the discourse. Dostoevsky signals the value of these hermeneutic principles twice in the third paragraph, both times through a repetition of the verb "to clarify" (uiasnit'). To call our attention to the verb's importance, Dostoevsky italicizes it each time it is used. It is like a flag waving from off the page. The only other lexical item to receive attention in this manner is the noun "truth" (pravda). The thematic, psychological, and intellectual links between the process of comprehension and the noun that constitutes its goal ("truth") should be clear enough. There is a third use of the verb's root (with alternate prefixation) that links Dostoevsky's commentary to that of the narrator's story. We have cited the passage already: "But [the story] truly does contain something fantastic, which is the form of the story itself, and it is this which I find it necessary to explain [poiasnit'] beforehand." ${ }^{4}$

The semantic difference between "to explain" ( $p o+j a s n-+i t$ ') and "to clarify" $(u+j a s n-+i t$ ') is rather well marked in terms of the opposition between author and narrator. The first is synonymous with the verb "to explain" (the alternately-prefixed verb $o b+j a s n-+i t$ '). The latter, with the prefix u-, refers to an individual's effort to render something comprehensible to himself or herself and to others. "To clarify" belongs to the pawnbroker's speech in that it encapsulates his quest to understand himself and what has happened to him and his wife, and also to explain himself before imagined interlocutors.

"To explain" (pojasnit'), on the other hand, belongs to Dostoevsky's authorial persona. Despite the difference between the two meanings of the verbs that share a common root (-jasn-), Dostoevsky suggests an affinity between his and his narrator's tasks and between their imagined interlocutors (Dostoevsky's implied readers and the narrator's imagined "ladies and gentlemen"). The narrator conceives of his implied interlocutors as judges. He attempts to "clarify" for himself what has happened to him and the Gentle Creature, and thus to justify himself before his projected conscience. Dostoevsky also stands before an audience, his readers, who have the capacity to judge his text as an aesthetic object. As readers of their shared texts, we are meant to assess both of the encoders at two distinct rhetorical levels. Author, narrator, and reader

44 Dostoevsky, A Writer's Diary, 677; 5. 
meet in the communication paradigm, each with discretely defined roles specified within the text and its pre-text "From the Author."

I have already mentioned that repetition functions in the introduction as a clue to the reader on how to proceed with the ensuing text. We have also seen that there are elements in the introduction which recur in the story as well, specifically the phrase "to gather into a point." There is yet another repeating form, morphological in this instance, which is of significance for the interpretations writer, narrator, and readers impose on or make of the text. That morphological form is opposed to the theme of gathering versus collecting. As noted, the centripetal idea "gather one's thoughts into a point" (or "to collect one's thoughts") is crucial to the tale's encoding and decoding. But no less important is its contrary-centrifugal motion. The verb that most dramatically encapsulates this opposition is "to jump out of" (vybrosit'sia). Needless to say, this verb plays a crucial role in the tale. It describes the event that precipitates the narrator's monologue. To put it in causal terms (and remembering the narrator's quest for a causal understanding of the tragedy), his wife's suicide brings him to reflect on his behavior, his identity, and his past. We note, of course, that motion in this instance is not toward a center, but away from it. In raw spatial terms, "to jump out of" is the riddle the narrator attempts to decipher. Just as much as there is a temporal opposition before/after at work in the text, there is a complementary spatial conflict between motion inward and outward.

The tension created by the opposition in/out is presented in physical as well as metaphorical terms. The pawnbroker understands that when he brings the Gentle Creature into his home, she will not leave it: "The fact is, she did not have the right to leave [vykhodit'] the apartment." 45 Her dramatic exit through the window, a symbolically rich threshold that places the Gentle Creature somewhere between heaven and earth (at least for a moment), brings an absolute halt to the conflict between them (which the pawnbroker has caused), that in turn animates the temporal opposition before/after.

The spatial opposition at work, inward/outward, is embedded in the two verbs (and their prefixes) "to gather" and "to exit." The first is prefixed by so-, which indicates, among other meanings, motion toward a center. The second, "to exit out of" is prefixed by $v y$-, which

45 Dostoevsky, A Writer's Diary, 694; 17. 
indicates motion from within outward. The narrator attempts to "gather his thoughts into a point" in order to understand the Gentle Creature's suicide which comes by her throwing herself out the window of their apartment. Centrifugal force represents the challenge to any possible unity the narrator's vain centripetal forcefulness might bring to the quest. In the opposition inward/outward, fragmentation clashes with the desire for unified understanding. The two motions are contrary. They are nonetheless causally related. His unforgiveable behavior causes her suicide; and her suicide (exit) causes him to gather his thoughts together and, perhaps, to work his way toward an understanding of his complicity in her death.

But nowhere is the significance of "outward" indicated more strongly than in the narrative's fifth chapter ("The Gentle Creature Rebels") where verbs of motion occur with the prefix $v y$ - seventy-four percent of the time. We recall that in this chapter the Gentle Creature challenges the pawnbroker to face up to a previous act of cowardice. In the exchange between them, the pawnbroker deliberately avoids using the verbs of motion that the Gentle Creature prefixes with $v y$-:

"Tell me, is it true they drove you out [vygnali] of the regiment because you were too cowardly to fight a duel [na duel'vyiti]?" she asked me suddenly, right out of the blue, her eyes flashing.

"It's true. By decision of the officers I was asked to leave the regiment, though I had sent in my resignation even before that." [The narrator avoids repeating the verbs prefixed by $v y$ - in his response.]

"They kicked you out [vygnali] as a coward?"

"Yes, the verdict was that I was a coward." [Again he avoids her verb and its prefix. $]^{46}$

In this dialogue, the literal and metaphoric stand in conflict. The Gentle Creature calls it like it is-his fellow officers drove him out of the regiment for failing to uphold its and their honor. The pawnbroker substitutes alternate descriptions, rather bookish and proper in form. His denial of her descriptors encapsulates the problem of the monologue where the narrator would like to substitute the truth of her accusation with an obfuscation. It is interesting that the pawnbroker's ambivalent movement toward the truth (as Dostoevsky describes it in the introduction) is forestalled by the centrifugal force of $v y$-, which

46 Dostoevsky, A Writer's Diary, 695; 18 (translation altered). 
he studiously avoids repeating. ${ }^{47}$ It creeps into his defensive speech in the second rejoinder to the Gentle Creature's accusation: "II refused the duel not as a coward but because I didn't want to submit to their tyrannical decree and challenge [vyzyvat'] a man who, in my view, had caused me no offense. You must realize,' I couldn't resist adding, 'that standing up to that sort of tyranny and accepting all the consequences meant showing [vykazat'] far more courage than fighting in a duel' ... She laughed spitefully." 48

In this text, the power of $v y$ - (exit) is superior to the power of so- (gathering in). But the hope that issues from the tortuous monologue comes from its ability to potentially invert the existential forces at work in the story that these prefixes suggest. As Dostoevsky states in the introduction; "Little by little [the narrator] really does make it clear and 'gather his thoughts into a point.' The series of memories the narrator has evoked irresistibly leads him at last to truth; and truth irresistibly elevates his mind and his spirit. By the end, even the tone of the story changes as compared with its confused beginning. The truth is revealed quite clearly and distinctly to the unhappy man-at least as far as he is concerned." 49

Dostoevsky's "at least as far as he is concerned" draws a line between the truth the narrator has "revealed quite clearly and distinctly" to himself, and another truth toward which we, with Dostoevsky as guide, incline. The "at least" contains a loophole through which any affinities between Dostoevsky's preparatory discourse (with its function of training readers how to decode the monologue) and the narrator's text disappear as into a black hole. Dostoevsky, it would seem, knows another truth that the story serves. The narrator, readers in tow, attempts to recreate it. Clearly, the narrator fails while believing the contrary. Readers beware.

The fourth and final paragraph of the introduction to "A Gentle Creature" turns our attention again to the fantastic in Dostoevsky's fiction. Having provided a lesson on how to defamiliarize language in

47 He does use the prefix $v y$ - with other verbs, just not with verbs of motion or verbs that imply motion. In his revised usage of $v y$-, he attempts to move his defense in a more positive direction. Incredibly, there is a symbolic battle taking place over the meaning of $v y$-, a battle mirroring the larger one.

48 Dostoevsky, A Writer's Diary, 695; 18.

49 Dostoevsky, A Writer's Diary, 677-678; 5. 
order to decode the text, Dostoevsky now addresses the "how" of his story. He seeks to make a second justification for the element in it he labels fantastic. He begins by saying that ". . . the process of the narrative goes on for a few hours, with breaks and interludes and in a confused and inconsistent form: at one point he talks to himself; then he seems to be addressing an invisible listener, a judge of some sort." ${ }^{50}$ Then, in a move typical of his approach to art, he turns to the problem of verisimilitude in the narrator's monologue-for-no-one:

But so it always happens in real life. If a stenographer had been able to eavesdrop and write down everything he said, it would be somewhat rougher and less finished than I have it here; still, it seems to me that the psychological structure would perhaps be just the same. And so it is this assumption of the stenographer recording everything (and whose account I simply polished) that I call the fantastic element in my story. Yet something quiet similar to this has already been employed more than once in art: Victor Hugo, for example, in his masterpiece The Last Day of a Man Condemned to Death, employed virtually this same device, and even though he did not depict any stenographer, he allowed an even greater breach of verisimilitude when he presumed that a man condemned to execution could (and would have time to) keep a diary, not only on his last day, but even in his last hour and literally in his last moment of life. But had he not allowed this fantastical element, the work itself-among the most real and most truthful of all his writingwould not have existed. ${ }^{51}$

Appealing to Hugo's precedent, Dostoevsky in effect asks his readers to willingly suspend disbelief. As in the case of Hugo's work, it is clearly something readers are wont to do when the work's aesthetics are of the quality we encounter in these two monologue-stories. ${ }^{52}$ But what is important to note is that Dostoevsky's integration of the fantastic in

50 Dostoevsky, A Writer's Diary, 678; 6.

51 Dostoevsky, A Writer's Diary, 678; 6. The preface to “A Gentle Creature" might work retroactively to instruct us on how to read the complex narrative that is Demons. I thank Gene Fitzgerald for this insight.

52 Interestingly, Hugo's The Last Day of a Man Condemned to Death has two prefaces, the first one a fictional preface written in dialogue form when the text was first published in 1827, and the second a direct authorial address in the 1832 edition. See Victor Hugo, The Last Day of a Condemned Man and Other Prison Writings, trans. Geoff Woollen (Oxford: Oxford University Press, 1992), 1-33. 
realist art ("in a higher sense") has more to do with literary technique than with the content of the story.

Dostoevsky works diligently in his preface to secure his readers' willingness to set aside any discomfort they might feel in regard to the story's technical implausibility. As we have seen, the third paragraph draws implied author, narrator, and readers into a web of mutual implication in the tasks of encoding and deciphering the text. Dostoevsky, in a letter to a correspondent, addressed the demands placed on the writer to win reader loyalty: “. . . the fantastic in art has limits and rules. The fantastic must be contiguous with the real to such a degree that you must almost believe it." 53 This "almost" is a bow to readers' rational minds. But before the pawnbroker's monologue begins, we are well prepared by Dostoevsky to suspend the "almost" he projects upon us.

Dostoevsky's extended description of how the pawnbroker goes about his self-inquiry instructs readers how to proceed with the text. But more than a willing suspension of disbelief is required. The reader must also be willing to apprehend Dostoevsky's language as a self-referential coding system that brings the introduction and the monologue into one overarching design. This means that readers will see language both as a medium and as an object. Ever mindful of language's suggestive power, Dostoevsky in effect advises his readers to be wary of the surface claims of utterance and to look deeper into its capacity to both create and resolve paradoxes. In effect, "A Gentle Creature" makes the same point we have already encountered in Notes from the House of the Dead. When we read Dostoevsky's prefaces, we need to be prepared to take his language for more than what it appears to be at first glance.

The language of his introductions demands the same kind of attention that Bakhtin gives to Dostoevsky's fictional texts. In effect, we are asked to view his prefaces as a subgenre, if only a minor one. The imminent rules of the subgenre prescribe a reader capable of apprehending the text both as language and as commentary on language. In order to implicate the reader in this hermeneutic, Dostoevsky, in his introduction to "A Gentle Creature," insinuates to the reader how to read the

53 Cited in Jackson, Dostoevsky's Quest for Form: A Study in His Philosophy of Art (New Haven: Yale University Press, 1966), 88. Jackson continues, in regard to the fantastic in Dostoevsky's art, "The role of the artist, then, is ultimately that of [a] seer" who seeks to reconcile the real and the ideal in the depiction of human beings, in whom "the real and the ideal merge" (91). 
entire text. Readers then view the introduction as more than a mute convention, as more than a mere technical exercise, but as an essential component of the creative process in which Dostoevsky seeks to engage them. In fact, in aiding readers to shift their focus from the text to the pre-text, and then to the con-text, Dostoevsky makes the creative process a theme of his discourse. And, as we have seen previously, the aim of that discourse is to struggle with fragmentation, with the forces of disunity expressed by $v y$-, in order to confront it with the power of $s o-$. The narrator may fail here, but it is essential that we readers do not. In the final analysis, this deeply humanistic purpose alters relationships between author, reader, and narrator, and thereby realizes the potential of the aesthetic word to gather people into that point which exists on the boundary of literature and reality. In the 1870 s, a period of fragmentation and social chaos, Dostoevsky found the unifying power of aesthetic language in "A Gentle Creature" in the text's very first words.

To return to the early remarks about The Diary of a Writer and its genre mélange-wherein many an entry leads to yet another, followed by a veer in thematic course to yet another entry that introduces yet another-the question of just what constitutes an introduction and what does not remains in the margins. A synchronic approach to the tale's first words delivers rather discrete readings of individual texts. On only one occasion, "The Boy at Christ's Christmas Party," does the grouping of pre-text, text, and post-text seem to matter. "Bobok" and "A Gentle Creature," however, appear very much to stand alone as thought experiments with self-contained authorial introductions and follow-on tales.

The preface to "Bobok" lays out a plan for reading just about all of Dostoevsky's fiction. The issue, in John Jones' words, is that “.. . one feels an urge to smoke Dostoevsky out with the question, 'Who's talking?" ${ }^{54}$ The question applies to all Dostoevsky' prose fiction. The introduction points, therefore, in two directions-toward Dostoevsky's oeuvre, on the one hand, and toward the The Diary, on the other. In "Bobok," Dostoevsky clarifies, at least, that it is not his voice we encounter, neither in this fiction nor in his fictional prefaces. Ironically (and this catches some of the fun Dostoevsky has with encoding texts), Dostoevsky tells us this in an authentic authorial introduction.

$\overline{54}$ John Jones, Dostoevsky (Oxford: Clarendon Press, 1983), 250. 
One presumes, therefore, that we can believe him (and this suggests some of the seriousness of Dostoevsky's engagement with texts, a seriousness that has to do with the contract he holds with his disparate readership). I am not certain, therefore, that we need relate the introduction to "Bobok" to any meta-textual theme. Drawing on Sidorov's notion that The Diary is first and foremost an aesthetic phenomenon, we may conclude that the foreword to "Bobok" only qualifies as art object on the margins, say as extra-textual commentary to which we appeal in a pinch, as when citing Dostoevsky's letters, notes, or journalism.

"The Boy at Christ's Christmas Party" certainly articulates The Diary's binary opposition between dystopia and utopia, and constitutes an aesthetic artifact (story). But its introduction is scattershot. First the story creeps up on Dostoevsky in "A Boy with His Arm Outstretched for Alms." Then it emerges as a theme for a fictional work that Dostoevsky, in his introduction, directly claims is hardly a fiction, but, given the existence of children beggars, a verifiable social reality. The introduction, again, comes from Dostoevsky's own voice. There is no fictionalizing here-he presents an argument about the validity of the story that follows. Our hearts are meant to be rent by the boy's lot. Dostoevsky leaves his projected readers little choice.

It would seem that when Dostoevsky introduces fiction himself, he asks his readers to follow his direct advice and to fall in line. This hardly suggests open-endedness, resistance to any final word, or dialogism. No wonder Dostoevsky altered this authorial impulse, for it hardly served his profound inclination to allow readers some room for independent interpretation. Consequently, in "The Gentle Creature," the final work of fiction containing a preface in the Diary, and consistent with all of the diary entries, we again hear directly from the authorial persona. The preface performs all the functions we have encountered previously in his works (with the exception of "Bobok" and "The Boy"). Within the implied author's prefatorial voice, an embedded foreword takes shape, one that propels us into the pawnbroker's monologue.

Dostoevsky may have learned in The Diary to be wary of his own voice position when developing a story. His return to prior prefatorial practice in "A Gentle Creature" suggests as much, as does his avoidance of an introduction altogether in "Dream of a Ridiculous Man" (1877). Why, then, would he insist on writing "From the Author" yet again in the preface to his final work of fiction, The Brothers Karamazov? 